\title{
Differential cytotoxic responses of PC12 cells chronically exposed to psychostimulants or to hydrogen peroxide
}

\author{
Teresa Cunha-Oliveira ${ }^{\mathrm{a}}$, A. Cristina Rego ${ }^{\mathrm{a}}$, Maria Teresa Morgadinho ${ }^{\mathrm{b}}$, \\ Tice Macedo $^{\mathrm{b}}$, Catarina Resende Oliveira $^{\mathrm{a}, *}$ \\ a Center for Neuroscience and Cell Biology and Institute of Biochemistry, Faculty of Medicine, \\ University of Coimbra, 3004-504 Coimbra, Portugal \\ ${ }^{\mathrm{b}}$ Institute of Pharmacology and Experimental Therapeutics, Faculty of Medicine, University of Coimbra, 3004-504 Coimbra, Portugal
}

Received 14 July 2005; received in revised form 19 August 2005; accepted 19 August 2005

Available online 19 October 2005

\begin{abstract}
Repeated abuse of stimulant drugs, cocaine and amphetamine, is associated with extraneuronal dopamine accumulation in specific brain areas. Dopamine may be cytotoxic through the generation of reactive oxygen species, namely hydrogen peroxide $\left(\mathrm{H}_{2} \mathrm{O}_{2}\right)$, resulting from dopamine oxidative metabolism. In this work, we studied the cytotoxicity in PC12 cells (a dopaminergic neuronal model) chronically and/or acutely exposed to cocaine or amphetamine, as compared to $\mathrm{H}_{2} \mathrm{O}_{2}$ exposure. Chronic cocaine treatment induced sensitization to acute cocaine insult and increased cocaine-evoked accumulation of extracellular dopamine, although no changes in dihydroxyphenylacetic acid (DOPAC) levels were observed. Moreover, dopamine was depleted in cells chronically exposed to amphetamine and acute amphetamine toxicity persisted in these cells, indicating that dopamine was not involved in amphetamine cytotoxicity. $\mathrm{PC} 12$ cells chronically treated with $\mathrm{H}_{2} \mathrm{O}_{2}$ were totally resistant to acute $\mathrm{H}_{2} \mathrm{O}_{2}$, but not to acute cocaine or amphetamine exposure, suggesting that the toxicity induced by these stimulant drugs is unrelated to adaptation to oxidative stress. Interestingly, chronic cocaine treatment largely, but not completely, protected the cells against a $\mathrm{H}_{2} \mathrm{O}_{2}$ challenge, whilst a decrement in intracellular ATP was observed. This study shows that chronic treatment of $\mathrm{PC} 12$ cells with cocaine or $\mathrm{H}_{2} \mathrm{O}_{2}$ modifies the cytotoxic response to an acute exposure to these agents.
\end{abstract}

(c) 2005 Elsevier Ireland Ltd. All rights reserved.

Keywords: Amphetamine; Cocaine; Drug abuse; Neurotoxicity; Oxidative stress

\section{Introduction}

The continuous abuse of drugs is sustained by the activation of the reward circuits in the brain, which is mainly associated with changes in dopaminergic activity (Di Chiara and Imperato, 1988). The stimulant drugs

\footnotetext{
* Corresponding author. Tel.: +351239820190.

E-mail address: catarina@cnc.cj.uc.pt (C.R. Oliveira).
}

amphetamine and cocaine are known to increase extraneuronal dopamine levels through different mechanisms. Amphetamine can redistribute the dopamine stored in vesicles to the cytoplasm (Sulzer et al., 1995), inducing non-vesicular release of dopamine, which is mediated by the plasma membrane dopamine transporter (DAT; Kahlig et al., 2005). On the other hand, cocaine inhibits DAT (Brown et al., 2001), preventing the reuptake of dopamine to the nerve terminal, thereby increasing the levels of dopamine in the synaptic cleft. 
One of the mechanisms of removal of dopamine from the extraneuronal space is via its metabolism, which may involve oxidation by monoamine oxidase (MAO), or its auto-oxidation. Both these mechanisms involve the generation of hydrogen peroxide $\left(\mathrm{H}_{2} \mathrm{O}_{2}\right)$, which may react with transition metal ions, via the Fenton-Haber Weiss reaction, originating the highly toxic hydroxyl radical $\left({ }^{\bullet} \mathrm{OH}\right)$. Thus, altered dopamine metabolism induces oxidative stress and cell death in dopaminergic cells (Jones et al., 2000).

Reactive oxygen species have been frequently associated with neuronal cell death due to the oxidation of carbohydrates, amino acids, phospholipids and nucleic acids (reviewed by Cadet and Brannock, 1998). Accordingly, acute exposure to $\mathrm{H}_{2} \mathrm{O}_{2}$ has been reported to induce apoptotic cell death in PC12 cells (Benedi et al., 2004; Jang and Surh, 2004). In contrast, cells chronically exposed to low concentrations of $\mathrm{H}_{2} \mathrm{O}_{2}$ become resistant to $\mathrm{H}_{2} \mathrm{O}_{2}$-induced toxicity (Wiese et al., 1995; Davies, 1999). Thus, acute $\mathrm{H}_{2} \mathrm{O}_{2}$ can be used as a model of cytotoxicity, whereas chronic treatment of PC12 cells with $\mathrm{H}_{2} \mathrm{O}_{2}$ is a model of cellular adaptation (Jackson et al., 1994).

Chronic exposure to the drugs of abuse in humans induces long-lasting changes in gene expression, and some of these changes may be correlated with the development of the compulsive behaviour associated with drug addiction (Rhodes and Crabbe, 2005, for review). Changes in gene expression induced by chronic drug exposure may underlie changes in the cellular responses to stress. These alterations are also in the basis for the development of sensitization or tolerance, in human drug abusers, in which the response to the same dose of a drug is increased or decreased, respectively. These processes contribute to the withdrawal symptoms and to increased motivation to drug abuse (Nestler, 2004). Thus, we hypothesise that chronic drug exposure may also be involved in altered responses to cytotoxic insults, such as an acute exposure to the same drug or to other cytotoxic stimuli, such as oxidative stress.

Taking this into account, we analysed the effect of chronic exposure of $\mathrm{PC} 12$ cells to non-toxic concentrations of cocaine, amphetamine or $\mathrm{H}_{2} \mathrm{O}_{2}$, as compared to PC12 cells non-exposed to the drugs of abuse (naïve cells). The cells were further treated with toxic concentrations of cocaine, amphetamine or $\mathrm{H}_{2} \mathrm{O}_{2}$ (acute exposure), based in our previous studies with PC12 cells exposed to the stimulant drugs (Oliveira et al., 2002). Our data support that the cytotoxic responses of PC12 cells are modified depending on the chronic exposure to cocaine, amphetamine or $\mathrm{H}_{2} \mathrm{O}_{2}$. In particular, increased toxicity of cocaine in cells chronically exposed to this stimulant drug may contribute to the behavioural sensitization of drug addicts after acute cocaine exposure.

\section{Material and methods}

\subsection{Materials}

Cocaine was obtained from the "Instituto da Droga e da Toxicodependência" (IDT, Lisbon, Portugal). Amphetamine, MayGrünwald and Giemsa solutions were obtained from Merck (Darmstadt, Germany). PC12 cells were obtained from ATCC (Manassas, VA, USA). RPMI and MTT were purchased from Sigma Chemical Co (St. Louis, MO, USA).

\subsection{Culture and treatment of PC12 Cells}

PC12 cells were cultured in $75 \mathrm{~cm}^{2}$ flasks, in RPMI 1640 medium supplemented with $10 \%(\mathrm{v} / \mathrm{v})$ horse serum, $5 \%(\mathrm{v} / \mathrm{v})$ bovine serum, $50 \mathrm{U} / \mathrm{mL}$ penicillin, and $50 \mathrm{mg} / \mathrm{mL}$ streptomycin. Cultures were maintained at $37^{\circ} \mathrm{C}$ in a humidified incubator containing $95 \%$ air and $5 \% \mathrm{CO}_{2}$. The cells were plated on poly-L-lysine coated multiwells at a density of 50,000 cells $/ \mathrm{cm}^{2}$ for MTT studies and $160,000 \mathrm{cells} / \mathrm{cm}^{2}$ for HPLC analysis.

For chronic treatment, PC12 cells were cultured for 7-12 months in RPMI medium supplemented with non-toxic concentrations of cocaine $(30 \mu \mathrm{M})$, amphetamine $(30 \mu \mathrm{M})$ or $\mathrm{H}_{2} \mathrm{O}_{2}(10 \mu \mathrm{M})$. Toxicity studies revealed similar responses in cells chronically exposed to the drugs or $\mathrm{H}_{2} \mathrm{O}_{2}$ from 7 to 12 months (data not shown). For acute treatment, the cells were exposed to toxic concentrations of cocaine $(3 \mathrm{mM})$, amphetamine (1 mM) or $\mathrm{H}_{2} \mathrm{O}_{2}(50-75 \mu \mathrm{M})$, for 24-96 h. Concentrations of the stimulant drugs (Oliveira et al., 2002) or $\mathrm{H}_{2} \mathrm{O}_{2}$ (data not shown) for chronic or acute experiments were previously established in PC12 cells.

\subsection{Assessment of cell viability}

Cell viability was measured using the 3-(4,5-dimethylthiazol-2-yl)-2,5-diphenyltetrazolium bromide (MTT) reduction assay at $570 \mathrm{~nm}$, as described previously (Oliveira et al., 2002). Briefly, the cells were incubated with $0.5 \mathrm{mg} / \mathrm{ml} \mathrm{MTT} \mathrm{in}$ $\mathrm{Na}^{+}$medium (in mM: $140 \mathrm{NaCl}, 5 \mathrm{KCl}, 1 \mathrm{MgCl}_{2}, 1 \mathrm{NaH}_{2} \mathrm{PO}_{4}$, $1.5 \mathrm{CaCl}_{2}, 5.6$ glucose, 20 HEPES, $\mathrm{pH} 7.4$ ) for $2 \mathrm{~h}$ and the precipitated salt was dissolved with $0.04 \mathrm{M} \mathrm{HCl}$ in isopropanol. The capacity of treated cells to reduce the tetrazolium salt was expressed as a percentage of absorbance in control cells.

\subsection{Measurement of dopamine and DOPAC levels}

The intracellular levels of dopamine and dihydroxyphenylacetic acid (DOPAC) were determined after cell extraction with $0.1 \mathrm{M}$ perchloric acid $\left(0-4{ }^{\circ} \mathrm{C}\right)$. The cells were centrifuged at $15,800 \times g$ for $10 \mathrm{~min}$, and the pellet was solubilized with $1 \mathrm{M} \mathrm{NaOH}$ for total protein analysis using the Sedmak method (Sedmak and Grossberg, 1977). The resulting supernatants, 
stored at $-80^{\circ} \mathrm{C}$, were extracted with alumina, using dihydroxybenzylamine (DHBA) as an internal standard, and assayed for dopamine and DOPAC analysis by HPLC with electrochemical detection, as described previously (Warnhoff, 1984). Dopamine accumulated in the cultured media upon acute exposure to cocaine or amphetamine, was determined using the same procedure.

\subsection{Morphological analysis of PC12 cells}

Cell morphology was evaluated by staining cell smears with May-Grünwald-Giemsa staining procedure. Naïve cells and cells chronically exposed to the stimulant drugs or to $\mathrm{H}_{2} \mathrm{O}_{2}\left(1 \times 10^{6}\right.$ cells $)$, before or after an acute exposure to $50 \mu \mathrm{M} \mathrm{H}_{2} \mathrm{O}_{2}$, were centrifuged at $200 \times g$ for $5 \mathrm{~min}$, ressuspended in $30 \mu \mathrm{l}$ of FBS and placed on a slide for analysis at the microscope. Cell smears were stained with May-Grünwald and Giemsa solutions. Cell morphology was analysed by optic microscopy using a Leitz Dialux 20 microscope associated with a digital camera.

\subsection{Measurement of intracellular ATP levels}

Intracellular ATP was determined after cell extraction with $0.3 \mathrm{M}$ perchloric acid $\left(0-4{ }^{\circ} \mathrm{C}\right)$. The cells were centrifuged at $15,800 \times g$ for $10 \mathrm{~min}$, and the pellet was solubilized with $1 \mathrm{M} \mathrm{NaOH}$ for total protein analysis using the Biorad protein assay (Biorad). The supernatants were neutralized with $3 \mathrm{M}$ $\mathrm{KOH}$ in $1.5 \mathrm{M}$ Tris, and centrifuged at $15,800 \times g$ for $10 \mathrm{~min}$. The resulting supernatants, stored at $-80^{\circ} \mathrm{C}$, were assayed for ATP determination, by separation in a reverse-phase HPLC, as described previously (Rego et al., 1997).

\subsection{Statistical analysis}

Data are the mean \pm S.E.M. from at least three experiments, performed in duplicate or triplicate. Statistical analysis was performed by the Student's $t$-test (a $P<0.05$ was considered significant).

\section{Results}

\subsection{Chronic cocaine treatment sensitizes PC12 cells to acute cocaine}

The toxicity of acute exposure to stimulant drugs was analyzed in naïve PC12 cells and cells chronically exposed to cocaine, amphetamine or $\mathrm{H}_{2} \mathrm{O}_{2}$, by following the MTT reduction assay (Fig. 1). The effect of long-term exposure to cocaine, amphetamine or $\mathrm{H}_{2} \mathrm{O}_{2}$ in cell viability was not possible to assess using the MTT assay because cells chronically exposed to these agents revealed an increased capacity to reduce MTT (about two-fold), which can result from an increase in cell proliferation and/or an increase in cell viability. Exposure

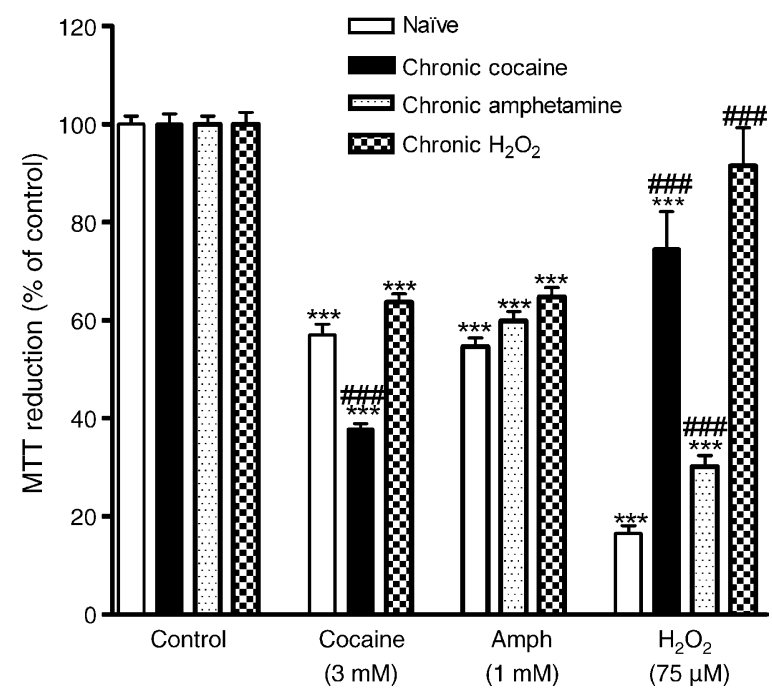

Fig. 1. Acute effect of cocaine, amphetamine or $\mathrm{H}_{2} \mathrm{O}_{2}$ on the viability of $\mathrm{PC} 12$ cells chronically exposed to the stimulant drugs of abuse or $\mathrm{H}_{2} \mathrm{O}_{2}$. Naïve PC12 cells or PC12 cells chronically exposed to cocaine, amphetamine or $\mathrm{H}_{2} \mathrm{O}_{2}$ for 7-12 months were incubated with $1 \mathrm{mM}$ amphetamine (amph) or $3 \mathrm{mM}$ cocaine for 4 days or $75 \mu \mathrm{M} \mathrm{H}_{2} \mathrm{O}_{2}$ for $24 \mathrm{~h}$. Cell viability was determined by the MTT reduction assay. Data were normalized in percentage of the respective controls, typically with absorbance values (at $570 \mathrm{~nm}$ ) of 0.42 (naïve), 0.84 (cocaine), 0.83 (amphetamine) and $0.90\left(\mathrm{H}_{2} \mathrm{O}_{2}\right)$. Data are the mean \pm S.E.M. of at least three experiments performed in triplicate. Statistical significance: ${ }^{* * * *} P<0.001$ as compared with the respective control; ${ }^{\# \#} P<0.001$ compared to naïve cells.

of dividing mammalian fibroblasts to low concentrations of oxidants (3-15 $\mathrm{M} \mathrm{M} \mathrm{H}_{2} \mathrm{O}_{2}$ ) was previously reported to stimulate cell growth and proliferation (Davies, 1999). Thus, it is possible that the increase in MTT reduction observed in cells chronically exposed to $\mathrm{H}_{2} \mathrm{O}_{2}$ or to the stimulants is due to an increase in cell proliferation rather than a direct effect in cellular reduction systems or in cell viability. Therefore, MTT reduction data were normalized as a percentage of control for each sub-cell line to evaluate the susceptibility induced by acute exposure to the agents, after different long-term pre-treatments. Acute cocaine exposure ( $3 \mathrm{mM}$, for $96 \mathrm{~h})$ decreased the viability of naïve cells by about $40 \%$, whereas in cells previously exposed to cocaine the decrement in cell viability was about $60 \%$. Thus, chronic cocaine sensitized PC12 cells to acute cocaine toxicity by about $20 \%$. In contrast, acute incubation with amphetamine $(1 \mathrm{mM}$, for $96 \mathrm{~h}$ ) induced the same decrease in cell viability (about $40 \%$ ) in naïve cells or in cells previously exposed to amphetamine (Fig. 1).

Since cocaine and amphetamine are known to interfere with the dopaminergic system, we evaluated the effects of chronic and acute exposure to these psychostimulants in the accumulation of extracellular dopamine 


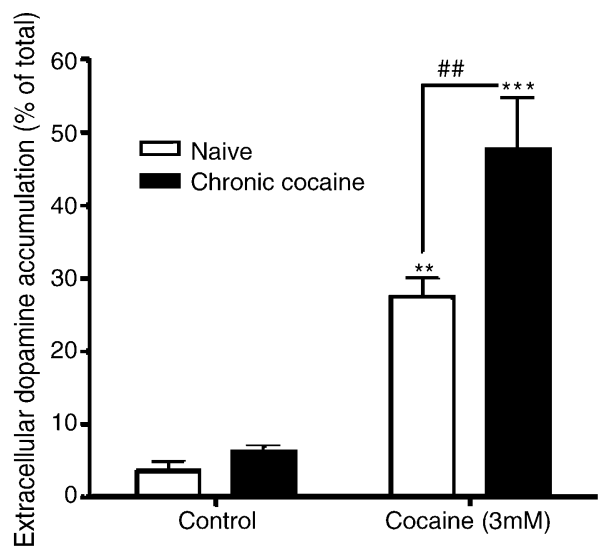

(A)
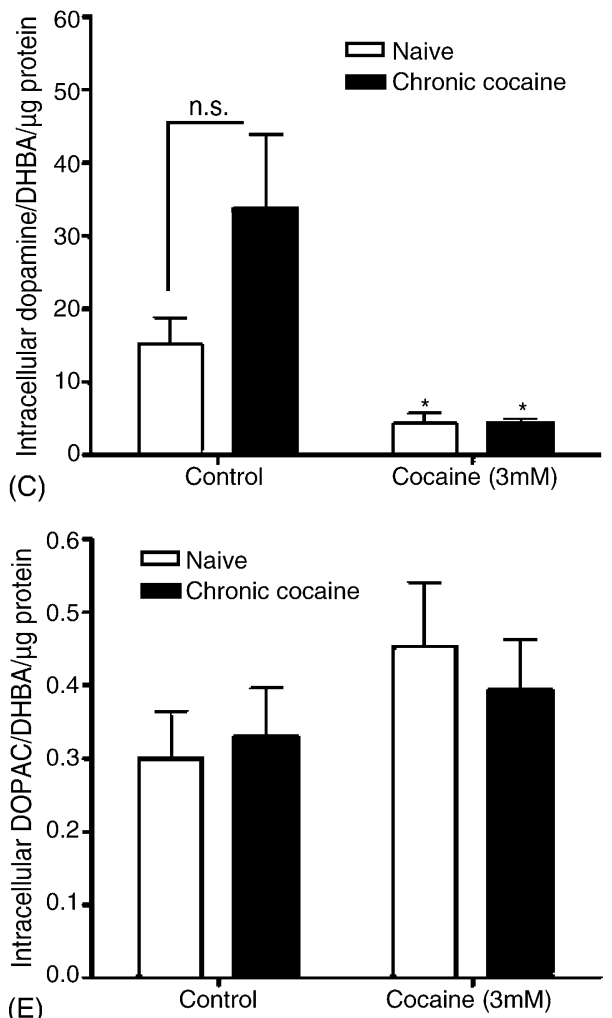

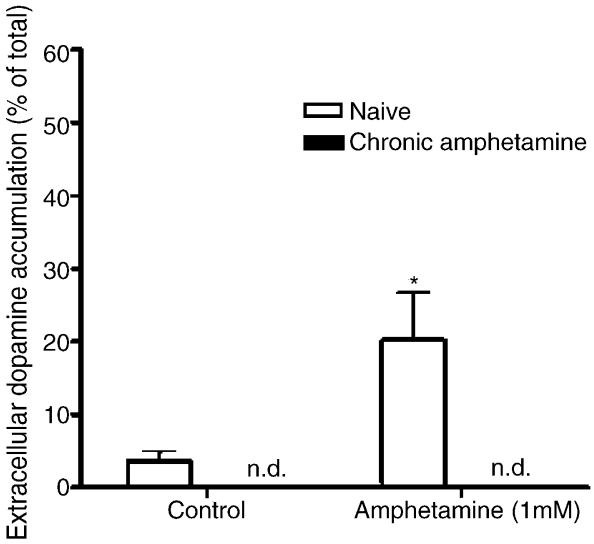

(B)
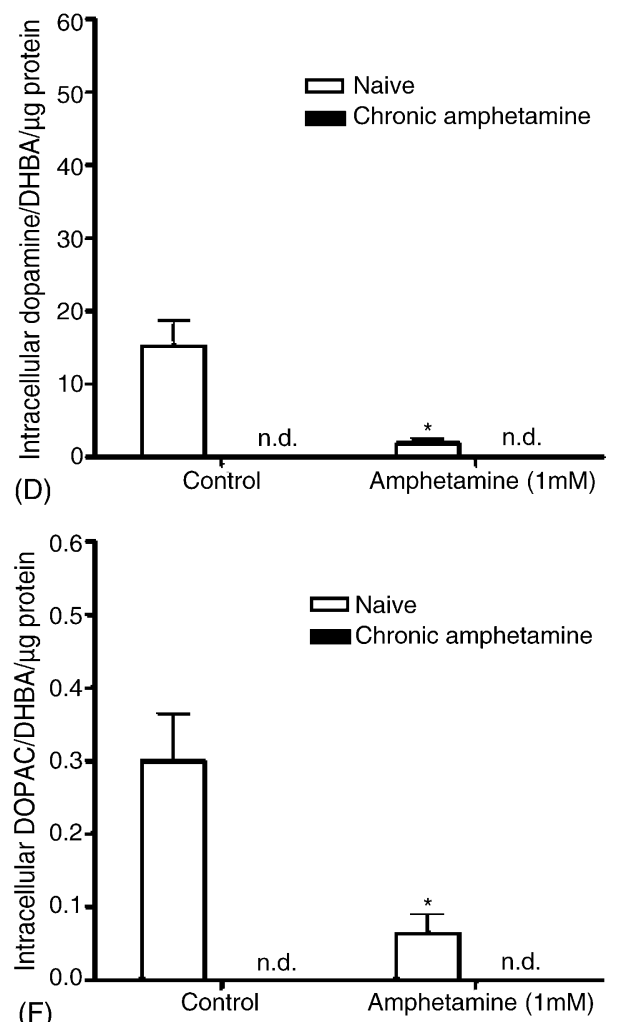

Fig. 2. Dopamine and DOPAC levels upon an acute exposure to cocaine or amphetamine, of naïve cells or cells chronically exposed to cocaine (A, $\mathrm{C}$ and $\mathrm{E}$ ) or amphetamine (B, D and F), for 7-12 months. The cells were acutely exposed to cocaine ( $3 \mathrm{mM})$ or amphetamine (1 mM), for $24 \mathrm{~h}$. Intra and extracellular dopamine and DOPAC levels were determined by HPLC with electrochemical detection. Data are the mean \pm S.E.M. of at least three experiments performed in triplicate. Statistical analysis: ${ }^{*} P<0.05,{ }^{* *} P<0.01$ and ${ }^{* * *} P<0.001$, compared with the respective control; ${ }^{\# \#} P<0.01$ compared to naïve cells. n.d.-non-detectable levels.

(Fig. 2A and B), intracellular dopamine levels (Fig. 2C and D) and the endogenous levels of its metabolite, DOPAC (Fig. 2E and F). Acute cocaine $(3 \mathrm{mM})$ or amphetamine $(1 \mathrm{mM})$ exposure for $24 \mathrm{~h}$ in naïve $\mathrm{PC} 12$ cells, increased extracellular dopamine accumulation, by about 7.6-fold and 5.6-fold, respectively (Fig. 2A and
B). Concordantly, under these conditions, a decrease in intracellular dopamine levels was observed in the presence of cocaine (decreased by 3.5 -fold) or amphetamine (decreased by 8.3-fold) (Fig. 2C and D). Moreover, acute amphetamine treatment largely decreased DOPAC levels, compared to the control, by 4.7-fold (Fig. 2F), 
whereas no significant changes were observed in cells exposed to cocaine (Fig. 2E). The decrement of DOPAC levels in cells exposed to amphetamine is consistent with the ability of amphetamine to inhibit MAO (Ramsay and Hunter, 2002).

In cells chronically treated with cocaine, further exposure to cocaine evoked a significant increase in extracellular dopamine by about $18.5 \%$ (Fig. 2A), when compared to naïve cells. This increase can be related with a non-statistical increase (by 2.2-fold) in intracellular dopamine levels in cells chronically exposed to cocaine, when compared to naïve cells (Fig. 2C). DOPAC levels were not significantly changed upon incubation with cocaine in cells chronically treated with the same drug, indicating that the extra dopamine was not metabolized by MAO (Fig. 2E). These data suggested that cocaine sensitization in cells chronically exposed to cocaine (Fig. 1) was related with an increase in cocaine-evoked extracellular dopamine accumulation.

Interestingly, no detectable levels of extracellular or intracellular dopamine (Fig. 2B and D) or intracellular DOPAC (Fig. 2F) were observed in cells chronically exposed to amphetamine. Thus, amphetamine toxicity in cells chronically exposed to amphetamine (Fig. 1) cannot be attributed to changes in extracellular or intracellular dopamine. Amphetamine-induced depletion of endogenous dopamine can be explained by long-term inhibition of tyrosine hydroxylase, the rate-limiting enzyme in the synthesis of dopamine (Bowyer et al., 1998). On the other hand, amphetamine is also known to decrease DAT activity (Kahlig et al., 2004), decreasing the reuptake of released dopamine.

\subsection{Cells chronically exposed to cocaine are partially resistant to $\mathrm{H}_{2} \mathrm{O}_{2}$}

Repeated exposure to $\mathrm{H}_{2} \mathrm{O}_{2}$ is known to induce cellular adaptation to acute $\mathrm{H}_{2} \mathrm{O}_{2}$ in $\mathrm{PC} 12$ cells (Jackson et al., 1994) and in other cell types (Wiese et al., 1995; Seong et al., 2002). In this study, we compared the toxicity of $\mathrm{H}_{2} \mathrm{O}_{2}$ in cells chronically exposed to the drugs of abuse or to $\mathrm{H}_{2} \mathrm{O}_{2}$. In naïve cells, acute exposure to $\mathrm{H}_{2} \mathrm{O}_{2}$ $(75 \mu \mathrm{M}$, for $24 \mathrm{~h})$ induced a decrease in cell viability by about $80 \%$ (Fig. 1). In contrast, in cells chronically exposed to $\mathrm{H}_{2} \mathrm{O}_{2}$ the same acute exposure did not significantly change cell viability, indicating that these cells are completely resistant to $\mathrm{H}_{2} \mathrm{O}_{2}$-induced toxicity and thus adapted to oxidative stress injury. Moreover, upon chronic exposure to $\mathrm{H}_{2} \mathrm{O}_{2}$, the toxicity of cocaine or amphetamine was similar to the toxicity observed in naïve cells (Fig. 1), suggesting that toxic effects medi- ated by the stimulant drugs were independent of adaptive changes induced by oxidative stress. Interestingly, cells chronically exposed to cocaine were more resistant to acute $\mathrm{H}_{2} \mathrm{O}_{2}$ than naïve cells, showing a decrease in cell viability by about $25 \%$ only (Fig. 1). In contrast, cells chronically exposed to amphetamine were only slightly more resistant to acute exposure to $\mathrm{H}_{2} \mathrm{O}_{2}$, (cell viability decreased by about $70 \%$ ), in comparison with naïve cells. No significant changes in Bcl2/Bax were observed in PC12 cells chronically exposed to cocaine, amphetamine or $\mathrm{H}_{2} \mathrm{O}_{2}$ (data not shown), thus not explaining the different susceptibility of these cells.

Since chronic cocaine appeared to mediate some resistance to $\mathrm{H}_{2} \mathrm{O}_{2}$ toxicity (Fig. 1), we also analyzed the morphology of PC12 cells and the intracellular levels of ATP upon an acute exposure to $\mathrm{H}_{2} \mathrm{O}_{2}$ in cells chronically treated with cocaine, which were compared to cells adapted to $\mathrm{H}_{2} \mathrm{O}_{2}$. Exposure of naïve cells to $\mathrm{H}_{2} \mathrm{O}_{2}$ $(50 \mu \mathrm{M}$, for $24 \mathrm{~h})$ induced a decrease in cell viability by about $70 \%$ (data not shown), similar to $75 \mu \mathrm{M} \mathrm{H_{2 } \mathrm { O } _ { 2 }}$ (Fig. 1). Under these conditions, the cells showed membrane blebbing and cell shrinkage (Fig. 3A), indicating some degree of lesion, compatible with the viability assay. In contrast, cells chronically exposed to $\mathrm{H}_{2} \mathrm{O}_{2}$ or to cocaine, showed a normal morphology after an acute exposure to $\mathrm{H}_{2} \mathrm{O}_{2}$ (Fig. 3A). These data were in accordance with data shown in Fig. 1.

Acute exposure of naïve cells to $\mathrm{H}_{2} \mathrm{O}_{2}$ induced a decrease in intracellular ATP levels, by about $23 \%$, whereas in cells chronically exposed to $\mathrm{H}_{2} \mathrm{O}_{2}$, ATP levels were maintained after an acute exposure to $\mathrm{H}_{2} \mathrm{O}_{2}$ (Fig. 3B), indicating a complete adaptation to oxidative stress-mediated changes in energy metabolism. However, in cells chronically exposed to cocaine, ATP levels were decreased by about $28 \%$ after exposure to $\mathrm{H}_{2} \mathrm{O}_{2}$. Thus, although cells chronically exposed to cocaine were more resistant to $\mathrm{H}_{2} \mathrm{O}_{2}$, intracellular ATP levels were still affected, suggesting that this may account for the increased susceptibility of cells chronically treated with cocaine, compared to cells treated with $\mathrm{H}_{2} \mathrm{O}_{2}$, when submitted to an acute $\mathrm{H}_{2} \mathrm{O}_{2}$ challenge (Fig. 1). Endogenous levels of ADP were not significantly affected by acute exposure to $\mathrm{H}_{2} \mathrm{O}_{2}$ in naïve cells or in cells chronically exposed to cocaine or $\mathrm{H}_{2} \mathrm{O}_{2}$ (data not shown), suggesting a decrease in ATP synthesis. The apparent lack of correlation between the high toxicity of acute $\mathrm{H}_{2} \mathrm{O}_{2}$ (Fig. 1) and the moderate decrease in ATP levels (Fig. 3), under similar experimental conditions, can be explained by the normalization of ATP levels over the protein content, which is not taken into consideration in the MTT reduction assay. 
(A)

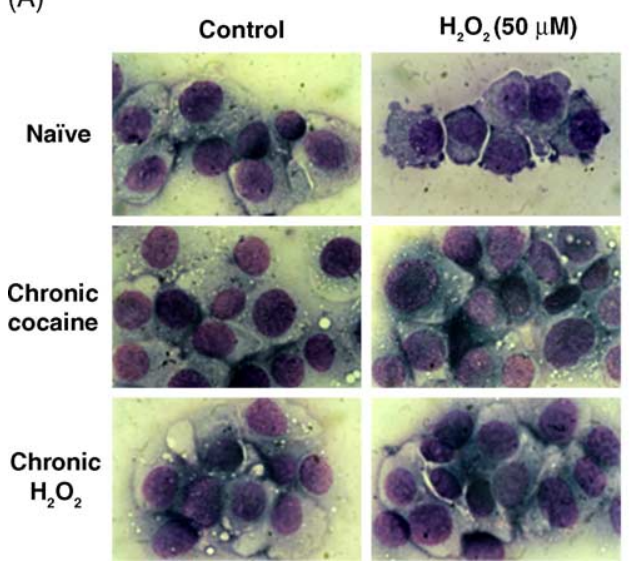

(B)

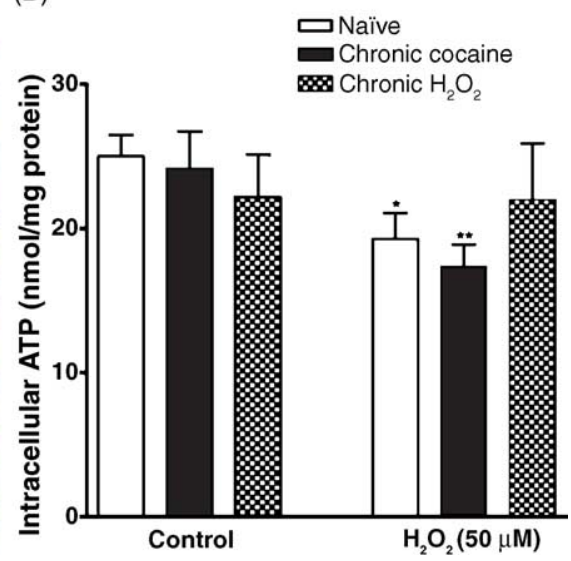

Fig. 3. Effect of an acute exposure to $\mathrm{H}_{2} \mathrm{O}_{2}$ in cells chronically exposed to cocaine ${ }^{2} \mathrm{H}_{2} \mathrm{O}_{2}$. (A) Cell morphology: cell smears were stained following May-Grunwald staining procedure and photographed under 100× magnification in a Leitz Dialux 20 light microscope associated with a camera. Note the formation of blebs and cell shrinkage upon exposure of naïve cells to $50 \mu \mathrm{M} \mathrm{H}_{2} \mathrm{O}_{2}$ for $24 \mathrm{~h}$. Images are representative of three experiments performed in duplicate. (B) Intracellular ATP levels were detected by HPLC with UV detection, before or after incubation with $50 \mu \mathrm{M}$ $\mathrm{H}_{2} \mathrm{O}_{2}$ for $24 \mathrm{~h}$. Data are the mean \pm S.E.M. of four experiments performed in triplicate. Statistical significance: ${ }^{*} P<0.05$ and ${ }^{* *} P<0.01$ compared to the control.

\section{Discussion}

\subsection{Cocaine sensitization and dopamine toxicity}

In this study, we showed that chronic cocaine increases the susceptibility of PC12 cells to acute cocaine toxicity, occurring concomitantly with enhanced cocaine-evoked dopamine release. PC12 cells chronically exposed to cocaine showed a non-statistical increase (by 2.2-fold) in intracellular dopamine levels, which could help to explain the increase in cocaineevoked extracellular dopamine accumulation observed in Fig. 2A, since dopamine release induced by cocaine is dependent on the vesicular pool of the neurotransmitter (Pifl et al., 1995). Repeated cocaine administration has been described to increase tyrosine hydroxylase activity, the rate-limiting enzyme in the biosynthesis of dopamine, in brain areas affected by cocaine, such as the ventral tegmental area (Sorg et al., 1993) or the substantia nigra (Vrana et al., 1993). Since reuptake of dopamine is inhibited by cocaine (Brown et al., 2001), increased intracellular levels of dopamine could be due to increased dopamine biosynthesis. Furthermore, under control conditions, extracellular dopamine levels in cells chronically exposed to cocaine were not statistically different from those in naïve cells (Fig. 2A). This observation could be due to an increase in expression of plasma membrane DAT, as reported previously in cells subjected to low concentrations of cocaine (Kahlig and Galli, 2003, for review). Thus, dopamine uptake during chronic treat- ment with cocaine could be preserved. Dopamine has been described to be cytotoxic to PC12 cells, inducing oxidative stress and apoptosis (Wang et al., 2005), in a process occurring through activation of NF-kB (Panet et al., 2001) or the SAPK/JNK pathway (Luo et al., 1998). Nevertheless, no evidences of changes in dopamine metabolization by MAO were found, as examined by the maintenance of DOPAC levels in cells exposed to cocaine (Fig. 2E). Importantly, the observed increase in cocaine-evoked dopamine release may be related to the behavioral sensitization induced by this drug (Williams and Steketee, 2005), which is defined by increased motor activity after repeated administration.

\subsection{Cocaine-induced partial resistance to $\mathrm{H}_{2} \mathrm{O}_{2}$ toxicity}

Chronic cocaine treatment was shown to partially protect $\mathrm{PC} 12$ cells against $\mathrm{H}_{2} \mathrm{O}_{2}$-induced toxicity, despite the decrease in ATP (by $\sim 28 \%$ ), which reflects metabolic dysfunction. In contrast, chronic treatment with $\mathrm{H}_{2} \mathrm{O}_{2}$ completely prevented $\mathrm{H}_{2} \mathrm{O}_{2}$ acute toxicity, as evaluated by MTT reduction (Fig. 1), cell morphology (Fig. 3A) and ATP levels (Fig. 3B). Several mechanisms have been proposed to explain cellular adaptation to $\mathrm{H}_{2} \mathrm{O}_{2}$. Moderate concentrations of $\mathrm{H}_{2} \mathrm{O}_{2}(0.25 \mathrm{mM}$, for $24 \mathrm{~h})$ increase the capacity of oxidant degradation by antioxidant enzymes, whereas lower concentrations $(0.05 \mathrm{mM}$, for $24 \mathrm{~h}$ ) block the signaling pathways triggered by toxic concentrations of $\mathrm{H}_{2} \mathrm{O}_{2}(1 \mathrm{mM})$ (Lee and Um, 1999). On 
the other hand, $\mathrm{H}_{2} \mathrm{O}_{2}$ adaptation may involve increased translocation of NF-kB to the nucleus, which contributes to increased cell survival (Kim et al., 2001a), not involving an increase in Bcl-2 or Bcl-XL (Lee and Um, 1999). Another signaling pathway regulated by $\mathrm{H}_{2} \mathrm{O}_{2}$ is the SAPK/JNK pathway, which is activated by high concentrations of $\mathrm{H}_{2} \mathrm{O}_{2}$ and suppressed by low adaptive concentrations of $\mathrm{H}_{2} \mathrm{O}_{2}$ (Kim et al., 2001b). The interference with these signaling pathways may confer increased cell resistance to $\mathrm{H}_{2} \mathrm{O}_{2}$, without increasing the capacity of degrading $\mathrm{H}_{2} \mathrm{O}_{2}$ (Lee and Um, 1999). Moreover, $\mathrm{H}_{2} \mathrm{O}_{2}$ adaptation induces cross-resistance to serum withdrawal and C2-ceramide by blocking their ability to activate the SAPK/JNK pathway (Kim et al., 2001b). Acute $\mathrm{H}_{2} \mathrm{O}_{2}$ toxicity has been reported to involve the inhibition of ADP phosphorylation, namely through the inhibition of glyceraldehyde-3-phosphate dehydrogenase, in glycolysis, and the ATP synthase complex, at the mitochondrial respiratory chain (Hyslop et al., 1988). This could account for the decrease in intracellular ATP levels observed in naïve PC12 cells and in cells chronically exposed to cocaine, following acute exposure to $\mathrm{H}_{2} \mathrm{O}_{2}$ (Fig. 3B).

Furthermore, proteomic analysis showed that adaptation to low concentrations of $\mathrm{H}_{2} \mathrm{O}_{2}$ may induce upregulation of proteins involved in energy metabolism, such as ATP synthase and glyceraldehyde-3-phosphate dehydrogenase (Seong et al., 2002), which may explain the maintenance of intracellular levels of ATP (Fig. 3B). In addition, proteomic analysis also suggests that upregulation of translation and RNA processing, chaperoning and redox regulation may also be in the basis for adaptation to $\mathrm{H}_{2} \mathrm{O}_{2}$ (Seong et al., 2002).

In cells chronically exposed to cocaine, $\mathrm{H}_{2} \mathrm{O}_{2}$ toxicity seemed to affect cell metabolism (Fig. 3B). Thus, the mechanism involved in the partial resistance of these cells to acute $\mathrm{H}_{2} \mathrm{O}_{2}$ is certainly not related to stimulation of energy metabolism. Similarly to $\mathrm{H}_{2} \mathrm{O}_{2}$, chronic cocaine was also reported to induce the activation of NF-kB (Ang et al., 2001) and AP-1 (Lee et al., 2001), two transcription factors described to be activated under oxidative stress conditions. Furthermore, repeated exposure to cocaine in rats was shown to increase the activity of glutathione peroxidase and superoxide dismutase, two antioxidant enzymes (Dietrich et al., 2005). Thus, the mechanism of partial resistance to $\mathrm{H}_{2} \mathrm{O}_{2}$ toxicity in cells chronically exposed to cocaine may possibly be explained by the activation of intracellular signaling pathways involved in the adaptation to $\mathrm{H}_{2} \mathrm{O}_{2}$, by low concentrations of cocaine. Nevertheless, high concentrations of cocaine induced toxicity in $\mathrm{H}_{2} \mathrm{O}_{2}$-treated cells, suggesting that toxic effects mediated by high con- centrations of cocaine are unrelated to adaptive changes induced by oxidative stress.

\subsection{Amphetamine-induced dopamine depletion and amphetamine toxicity}

Chronic exposure to amphetamine-induced dopamine depletion (Fig. 2B and D). Nevertheless, acute amphetamine toxicity persisted in cells lacking dopamine (Fig. 1), indicating that dopamine is not involved in amphetamine toxicity. In vivo studies demonstrated that amphetamine toxicity is associated with a decrease in striatal dopamine levels (Wagner et al., 1980), decreased tyrosine hydroxylase activity (Ellison et al., 1978) and loss of dopamine transporter activity (Saunders et al., 2000). Although toxic mechanisms caused by amphetamine have been largely associated with the dopaminergic system, a more general mechanism of toxicity for amphetamine was also described, which involves disruption of the mitochondrial potential due to the net positive charge of amphetamine (Davidson et al., 2001). In accordance, we have previously observed that acute exposure of $\mathrm{PC} 12$ cells to amphetamine $(1 \mathrm{mM}$, for $96 \mathrm{~h})$ resulted in a decrease in intracellular ATP/ADP ratio (Oliveira et al., 2002). Moreover, increasing evidences suggest that amphetamine, or amphetamine derivatives, can have toxic effects in non-dopaminergic cells, such as cerebellar granule cells exposed in vitro to $4 \mathrm{mM}$ methamphetamine or methylenedioxy-methamphetamine (Jimenez et al., 2004) and rat medium spiny projection neurons in the striatum, upon in vivo exposure to four times $10 \mathrm{mg} / \mathrm{kg}$ D-amphetamine (Krasnova et al., 2005).

In conclusion, this study provides further data confirming functional alterations in dopaminergic cells chronically exposed to amphetamine or cocaine. We showed that chronic treatment with amphetamine induced dopamine depletion, which did not affect amphetamine or $\mathrm{H}_{2} \mathrm{O}_{2}$ cytotoxicity in these cells. Furthermore, exposure to cocaine increased the sensitivity to an acute cocaine exposure, along with cocaine-evoked extracellular dopamine accumulation, which may be related with increased motor activity after repeated administration of this drug of abuse (Williams and Steketee, 2005). Moreover, in contrast to prolonged exposure to $\mathrm{H}_{2} \mathrm{O}_{2}$, chronic cocaine induced a partial resistance to $\mathrm{H}_{2} \mathrm{O}_{2}$-mediated cytotoxicity, which was not correlated with the maintenance of energy levels. These data suggest that distinct cellular mechanisms operate during prolonged exposure to cocaine or $\mathrm{H}_{2} \mathrm{O}_{2}$, implicating major changes in cell susceptibility. 


\section{Acknowledgements}

This work was supported by FCT, Portugal: POCTI/SAU-FCF/58330/2004 and SFRH/BD/10910/ 2002. The authors are grateful to Dr. Maria Teresa Lopes da Silva (Institute of Pathological Anatomy, Hematopathology section, Faculty of Medicine University of Coimbra, Portugal), Sílvia Sousa Neves and Prof. Ana Bela Sarmento (Center for Neuroscience and Cell Biology, University of Coimbra) for helpful advices provided for the morphological studies and to Dr. Maria Sancha Santos (Center for Neuroscience and Cell Biology, University of Coimbra) for helping with HPLC analysis of ATP levels.

\section{References}

Ang, E., Chen, J., Zagouras, P., Magna, H., Holland, J., Schaeffer, E., Nestler, E.J., 2001. Induction of nuclear factor-kappaB in nucleus accumbens by chronic cocaine administration. J. Neurochem. 79, 221-224.

Benedi, J., Arroyo, R., Romero, C., Martin-Aragon, S., Villar, A.M., 2004. Antioxidant properties and protective effects of a standardized extract of Hypericum perforatum on hydrogen peroxideinduced oxidative damage in PC12 cells. Life Sci. 75, 12631276.

Bowyer, J.F., Frame, L.T., Clausing, P., Nagamoto-Combs, K., Osterhout, C.A., Sterling, C.R., Tank, A.W., 1998. Long-term effects of amphetamine neurotoxicity on tyrosine hydroxylase mRNA and protein in aged rats. J. Pharmacol. Exp. Ther. 286, 10741085.

Brown, J.M., Hanson, G.R., Fleckenstein, A.E., 2001. Regulation of the vesicular monoamine transporter-2: a novel mechanism for cocaine and other psychostimulants. J. Pharmacol. Exp. Ther. 296, 762-767.

Cadet, J.L., Brannock, C., 1998. Free radicals and the pathobiology of brain dopamine systems. Neurochem. Int. 32, 117-131.

Davidson, C., Gow, A.J., Lee, T.H., Ellinwood, E.H., 2001. Methamphetamine neurotoxicity: necrotic and apoptotic mechanisms and relevance to human abuse and treatment. Brain Res. Brain Res. Rev. 36, 1-22.

Davies, K.J., 1999. The broad spectrum of responses to oxidants in proliferating cells: a new paradigm for oxidative stress. IUBMB Life 48, 41-47.

Di Chiara, G., Imperato, A., 1988. Drugs abused by humans preferentially increase synaptic dopamine concentrations in the mesolimbic system of freely moving rats. Proc. Natl. Acad. Sci. U.S.A. 85, 5274-5278.

Dietrich, J.B., Mangeol, A., Revel, M.O., Burgun, C., Aunis, D., Zwiller, J., 2005. Acute or repeated cocaine administration generates reactive oxygen species and induces antioxidant enzyme activity in dopaminergic rat brain structures. Neuropharmacology 48, 965-974.

Ellison, G., Eison, M.S., Huberman, H.S., Daniel, F., 1978. Longterm changes in dopaminergic innervation of caudate nucleus after continuous amphetamine administration. Science 201, 276-278.

Hyslop, P.A., Hinshaw, D.B., Halsey Jr., W.A., Schraufstatter, I.U., Sauerheber, R.D., Spragg, R.G., Jackson, J.H., Cochrane, C.G., 1988. Mechanisms of oxidant-mediated cell injury. The glycolytic and mitochondrial pathways of ADP phosphorylation are major intracellular targets inactivated by hydrogen peroxide. J. Biol. Chem. 263, 1665-1675.

Jackson, G.R., Sampath, D., Werrbach-Perez, K., Perez-Polo, J.R., 1994. Effects of nerve growth factor on catalase and glutathione peroxidase in a hydrogen peroxide-resistant pheochromocytoma subclone. Brain Res. 634, 69-76.

Jang, J.H., Surh, Y.J., 2004. Possible role of NF-kappaB in Bcl-X(L) protection against hydrogen peroxide-induced PC12 cell death. Redox Rep. 9, 343-348.

Jimenez, A., Jorda, E.G., Verdaguer, E., Pubill, D., Sureda, F.X., Canudas, A.M., Escubedo, E., Camarasa, J., Camins, A., Pallas, M., 2004. Neurotoxicity of amphetamine derivatives is mediated by caspase pathway activation in rat cerebellar granule cells. Toxicol. Appl. Pharmacol. 196, 223-234.

Jones, D.C., Gunasekar, P.G., Borowitz, J.L., Isom, G.E., 2000. Dopamine-induced apoptosis is mediated by oxidative stress and is enhanced by cyanide in differentiated PC12 cells. J. Neurochem. 74, 2296-2304.

Kahlig, K.M., Binda, F., Khoshbouei, H., Blakely, R.D., McMahon, D.G., Javitch, J.A., Galli, A., 2005. Amphetamine induces dopamine efflux through a dopamine transporter channel. Proc. Natl. Acad. Sci. U.S.A. 102, 3495-3500.

Kahlig, K.M., Galli, A., 2003. Regulation of dopamine transporter function and plasma membrane expression by dopamine, amphetamine, and cocaine. Eur. J. Pharmacol. 479, 153-158.

Kahlig, K.M., Javitch, J.A., Galli, A., 2004. Amphetamine regulation of dopamine transport. Combined measurements of transporter currents and transporter imaging support the endocytosis of an active carrier. J. Biol. Chem. 279, 8966-8975.

Kim, D.K., Cho, E.S., Lee, B.R., Um, H.D., 2001a. NF-kappa B mediates the adaptation of human U937 cells to hydrogen peroxide. Free Radic. Biol. Med. 30, 563-571.

Kim, D.K., Cho, E.S., Seong, J.K., Um, H.D., 2001b. Adaptive concentrations of hydrogen peroxide suppress cell death by blocking the activation of SAPK/JNK pathway. J. Cell Sci. 114, 43294334.

Krasnova, I.N., Ladenheim, B., Cadet, J.L., 2005. Amphetamine induces apoptosis of medium spiny striatal projection neurons via the mitochondria-dependent pathway. FASEB J.

Lee, B.R., Um, H.D., 1999. Hydrogen peroxide suppresses U937 cell death by two different mechanisms depending on its concentration. Exp. Cell Res. 248, 430-438.

Lee, Y.W., Hennig, B., Fiala, M., Kim, K.S., Toborek, M., 2001. Cocaine activates redox-regulated transcription factors and induces TNF-alpha expression in human brain endothelial cells. Brain Res. 920, 125-133.

Luo, Y., Umegaki, H., Wang, X., Abe, R., Roth, G.S., 1998. Dopamine induces apoptosis through an oxidation-involved SAPK/JNK activation pathway. J. Biol. Chem. 273, 3756-3764.

Nestler, E.J., 2004. Molecular mechanisms of drug addiction. Neuropharmacology 47 (Suppl. 1), 24-32.

Oliveira, M.T., Rego, A.C., Morgadinho, M.T., Macedo, T.R., Oliveira, C.R., 2002. Toxic effects of opioid and stimulant drugs on undifferentiated PC12 cells. Ann. N. Y. Acad. Sci. 965, 487496.

Panet, H., Barzilai, A., Daily, D., Melamed, E., Offen, D., 2001. Activation of nuclear transcription factor kappa B (NF-kappaB) is essential for dopamine-induced apoptosis in PC12 cells. J. Neurochem. 77, 391-398.

Pifl, C., Drobny, H., Reither, H., Hornykiewicz, O., Singer, E.A., 1995. Mechanism of the dopamine-releasing actions of amphetamine 
and cocaine: plasmalemmal dopamine transporter versus vesicular monoamine transporter. Mol. Pharmacol. 47, 368-373.

Ramsay, R.R., Hunter, D.J., 2002. Inhibitors alter the spectrum and redox properties of monoamine oxidase A. Biochim. Biophys. Acta 1601, 178-184.

Rego, A.C., Santos, M.S., Oliveira CR, 1997. Adenosine triphosphate degradation products after oxidative stress and metabolic dysfunction in cultured retinal cells. J. Neurochem. 69, 1228-1235.

Rhodes, J.S., Crabbe, J.C., 2005. Gene expression induced by drugs of abuse. Curr. Opin. Pharmacol. 5, 26-33.

Saunders, C., Ferrer, J.V., Shi, L., Chen, J., Merrill, G., Lamb, M.E., Leeb-Lundberg, L.M., Carvelli, L., Javitch, J.A., Galli, A., 2000. Amphetamine-induced loss of human dopamine transporter activity: an internalization-dependent and cocaine-sensitive mechanism. Proc. Natl. Acad. Sci. U.S.A. 97, 6850-6855.

Sedmak, J.J., Grossberg, S.E., 1977. A rapid, sensitive, and versatile assay for protein using Coomassie brilliant blue G250. Anal. Biochem. 79, 544-552.

Seong, J.K., Kim, D.K., Choi, K.H., Oh, S.H., Kim, K.S., Lee, S.S., Um, H.D., 2002. Proteomic analysis of the cellular proteins induced by adaptive concentrations of hydrogen peroxide in human U937 cells. Exp. Mol. Med. 34, 374-378.

Sorg, B.A., Chen, S.Y., Kalivas, P.W., 1993. Time course of tyrosine hydroxylase expression after behavioral sensitization to cocaine. J. Pharmacol. Exp. Ther. 266, 424-430.
Sulzer, D., Chen, T.K., Lau, Y.Y., Kristensen, H., Rayport, S., Ewing, A., 1995. Amphetamine redistributes dopamine from synaptic vesicles to the cytosol and promotes reverse transport. J. Neurosci. 15, 4102-4108.

Vrana, S.L., Vrana, K.E., Koves, T.R., Smith, J.E., Dworkin, S.I., 1993. Chronic cocaine administration increases CNS tyrosine hydroxylase enzyme activity and mRNA levels and tryptophan hydroxylase enzyme activity levels. J. Neurochem. 61, 2262-2268.

Wagner, G.C., Ricaurte, G.A., Johanson, C.E., Schuster, C.R., Seiden, L.S., 1980. Amphetamine induces depletion of dopamine and loss of dopamine uptake sites in caudate. Neurology 30, 547-550.

Wang, L.Z., Sun, W.C., Zhu, X.Z., 2005. Ethyl pyruvate protects PC12 cells from dopamine-induced apoptosis. Eur. J. Pharmacol. 508, 57-68.

Warnhoff, M., 1984. Simultaneous determination of norepinephrine, dopamine, 5-hydroxytryptamine and their main metabolites in rat brain using high-performance liquid chromatography with electrochemical detection. Enzymatic hydrolysis of metabolites prior to chromatography. J. Chromatogr. 307, 271-281.

Wiese, A.G., Pacifici, R.E., Davies, K.J., 1995. Transient adaptation of oxidative stress in mammalian cells. Arch. Biochem. Biophys. 318, 231-240.

Williams, J.M., Steketee, J.D., 2005. Time-dependent effects of repeated cocaine administration on dopamine transmission in the medial prefrontal cortex. Neuropharmacology 48, 51-61. 